\title{
Fostering European Identity
}

\section{Sarah Ciaglia}

London School of Economics and Political Science

\section{Clemens Fuest}

Ifo Institut and Ludwig-Maximilians-University Munich

\section{Friedrich Heinemann*}

ZEW Mannheim and University of Heidelberg

\section{$\Gamma$ Crossef http://dx.doi.org/10.5755/j01.eis.1.14.25492}

Over recent years, the concept of 'European identity' has received increasing scholarly attention. Despite this progress, political initiatives to foster a shared feeling of Europeanness still appear to be designed largely ad hoc. This contribution aims at providing a link between the existing state of knowledge and policy approaches to promote European identity. With a target group perspective, we develop a classification of measures to promote European identity. This classification is based on the distinctions between a 'civic' and a 'cultural' European identity. Within this framework, we assess seven proposals: transnational party lists for the European Parliament, an EU Citizens' Assembly, EU consular offices, a Pensioners' Erasmus, a 'European Waltz' program, an EU public service broadcaster, and a European bank holiday. We conclude that current identity strategies suffer from too narrow target groups that already tend to have a European perspective.

KEYWORDS: Erasmus, civic identity, cultural identity, Adonnino Report.

Acknowledgement: We gratefully acknowledge financial support by Lutz Helmig. We also thank two anonymous reviewers for their helpful advice.

A common identity within groups fosters mutual trust and cooperation (Akerlof \& Kranton, 2000). This fundamental insight makes 'identity' a relevant concept also for the functioning of political organizations and it is not surprising that issues of 'European identity' have received substantial attention in the study of the European integration process as well (see for example: Cram, 2012; Kaina, 2013; Westle \& Segatti, 2016). Similar to national identity as one driving factor for the emergence of the nation state, some type of European identity is seen as a stabilizer for the existence and further evolution of the political institutions of Europe such as the European Union. Increasingly, it is acknowledged that public opinion towards the European Union is not solely determined by economic and utilitarian 'hard' facts but also by 'soft' factors that encompass identity (Mitchell, 2014; Van Klingeren, Boomgaarden, \& De Vreese, 2013). In analogy to the common identity of any other social group, identity of a European type would foster mutual trust of Europeans and, hence, simplify cooperation and the search for compromises. ${ }^{1}$ With these arguments, European identity should be conducive for a cooperative approach that avoids a perspective of narrow nation-

* corresponding author, email: friedrich.heinemann@zew.de3

1 For experimental evidence on the link between European identity and cooperation see La Barbera and Ferrara, (2012). According to these results, there are direct and indirect effects of European identity on cooperative behavior. The indirect effect is mediated by the generation of trust.

EIS 14/2020

Fostering European Identity

Submitted 03/2020

Accepted for

publication 07/2020

\section{Abstract}

\section{Introduction}

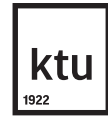

European Integration Studies No. 14 / 2020, pp. 9-25 doi.org/10.5755/j01.eis.1.14.25492 
al self-interest. Hence, it is not surprising that the concept receives particular attention in a critical stage of European integration that has experienced new serious conflicts and cleavages with the euro area debt crisis, the refugee issue, the rise of anti-European movements and the Brexit.

The awareness that European identity is a relevant constraint for the future of the integration process is not new. As early as 1973, at the Copenhagen Summit, the Heads of State adopted a brief declaration on European identity emphasizing the 'common heritage, interests and special obligations' as essential for Member States' foreign policy (Commission of the European Communities, 1973). While the terminology was vague in these early years, a first, more substantial milestone was the 'Adonnino Report' (Commission of the European Communities, 1985). With the mandate from the Fontainebleau European Council, a committee under the chairmanship of Pietro Adonnino produced a comprehensive list of measures and projects to advance a common identity, some of which (European flag and anthem, student exchange programs) paved the way for the most prominent identity-constructing approaches of the following decades like Erasmus. Identity-supporting initiatives since the Adonnino Report have been largely motivated ad hoc and have lacked a closer link to the academic literature. These superficial approaches have led to a problematic narrowness of strategies. For example, in the tradition of the Adonnino Report, measures to foster cross-border mobility of students and apprentices through the current Erasmus+ program, the EU student card or the promotion of European universities receive substantial attention in most political reflections on how to foster European identity (a recent prominent example is the Commission's Gothenburg Communication from November 2017: European Commission, 2017). However, this almost exclusive focus on the young and mobile generation with an already well-developed European perspective may be unbalanced. It may not sufficiently reflect the overwhelming empirical evidence that very different target groups (for instance middle-aged or elderly generations without tertiary education) with a lack of opportunity for transnational contacts might be much more crucial addressees.

Here our contribution comes in. Our key objective is to link a well-developed theoretical and empirical strand in the European integration literature to the ongoing policy debate on appropriate strategies for fostering European identity. Thus, we hope to provide a contribution that can inform European policymakers to develop better-targeted strategies at a critical stage of the integration process.

For this purpose, we systematize and assess various triggers that might stimulate identity formation on a European level. Based on a synthesis of the theoretical and empirical literature of the last years, we identify important target groups that new programs should address and we develop a classification of measures. Hence, we do not provide an additional primary study to the huge existing literature but rather approach the issue from a meta-analytical perspective. Within this framework, we assess the rationale of a few exemplary specific proposals for new identity triggers in more detail that are: transnational party lists, citizens' assemblies, a European public broadcaster, EU consulates, a 'European Waltz' program, a Pensioners' Erasmus, and a European bank holiday. Some of these approaches are new, some have been discussed since the time of the Adonnino Report. We sketch the history, basic ideas and limitations behind these models and show how they reflect different insights of identity research and for which target group they are promising. We proceed as follows: In a first step, we briefly take stock of the definitions and concepts of European identity as they have emerged over recent years (section 2) followed by a brief sketch of aggregate trends in European identity over the last four decades (section 3). Our review of the empirical literature describes the robustly significant correlates of European identity on an individual level (section 4). Based on these insights, we propose a target-group specific classification of identity fostering measures (section 5). Section 6 develops in more detail our seven exemplary measures followed by conclusions on the limits and risks of any European identity fostering strategy. 
The term 'European identity' can in general be described as a feeling of being European "as an integral part of one's own social identity". ${ }^{2}$ The attempts to conceptualize European identity are vast and comprehensive and have led to various refinements (Carey, 2002; Friese \& Wagner, 2002; Kaina, 2013; Kaina, Karolewski, \& Kuhn, 2015; White, 2012).

Excellent data availability has made the straightforward conceptualization of identification 'as European' highly influential. The so called 'Moreno question' 3 is the following one: "In the near future, do you see yourself as (1) [nationality] only, (2) [nationality] and European, (3) European and [nationality] or (4) European only?". This question is regularly asked in the European Commission's bi-annual standard Eurobarometer survey and widely used in the empirical literature.

Although this framing dominates the empirical research, the literature's understanding is much richer. Cram (2012) clarifies that an implicit and latent type of identity is quite distinct from the explicit identity 'as European'. The latter is also not fully informative about the intensity of attachment towards Europe or even 'EU support'. No matter how 'European identity' is precisely defined, there is a consensus that it is contingent. Like regional and national loyalties shift as a consequence of external changes (Cram, 2012 on Scottish identity in the Thatcher era) the same holds for European identity. The insight that a European identity is not strictly exogenous is an important message for any policy attempt to influence the formation and path of identity evolution.

One of the conceptual refinements of the identity literature that is particularly valuable for a classification of policy proposals is the distinction between a civic and a cultural component of European identity (Bruter, 2003). A European 'civic identity' refers to the perception to be part of a European political system or even a 'European state' that defines rules, laws and rights with relevance for one's own life. A focus on the civic dimension would largely equate 'Europe' with 'European Union'. A European 'cultural identity' is independent from these political perceptions and labels the perception that fellow Europeans are closer than non-Europeans because of shared culture, values or history. This distinction is important for the classification of identity-activating measures since, typically, the civic and cultural dimensions of identity will respond differently. Bruter (2004) finds that 'cultural' identifiers have to do with peace, harmony, the fading of historical divisions and co-operation between similar people and cultures, whereas the images of Europe held by 'civic' identifiers are related to the experience of open borders, mobility of citizens, common civic area, and economic prosperity.

The civic dimension of European identity is particularly related to the perceived 'legitimacy' of the (political) European project. Therefore, for the purpose of our classification, the standard distinction between 'input legitimacy' and 'output legitimacy' (Hobolt, 2012; Scharpf, 1999) is also helpful. Triggers that foster civic identity through the 'input'-channel refer to the institutions and processes that lead to political decisions in Europe with a (perceived) high voter involvement. Approaches towards more European identity through the output-channel concentrate on a good performance of European policies that effectively deliver salient public goods to citizens.

Figure 1 presents the general trend of European identity from Eurobarometer data between the early 1990s and 2019. Over these decades, the "(NATIONALITY) only" (e.g. "French only") answer competes with the "(NATIONALITY) and European" answer for the first place. Since 2012, the "double identity" answer (seeing oneself as both having a national and a European identity) has increasingly beaten the "national only" answer. Since then, also the "European and (NATIONAL-

2 For a detailed discussion of the definition social and political identity see Kaina and Karolewski (2013) and Dehdari and Gehring (2017).

3 It was named after sociologist Luis Moreno Fernández (1986), who first introduced such a question to study sub-national identity of Scots and Catalans with regard to Britain and Spain, respectively.
Conceptualization of European identity

Trends of European identity over time 


\section{Figure 1}

Moreno question measuring European identity, 1992-2019, EU total
ITY)" answer has advanced that puts the European identity even before the national one. Taken together, the share of respondents that state to possess some type of European identity (either exclusively or in combination with a national identity) has fluctuated over these three decades between a minimum of $51 \%$ in 2010 and a maximum of $65 \%$ for the most recent surveys in 2019 .

Obviously, there seems to be an impact of crisis and crisis adjustments on this development. The minimum was reached in a year that was characterized by the immediate economic and social fallout from the global financial crisis and which, on top, marked the start of the euro area debt crisis. A possible explanation for the continuous recovery of European identity since then is that events like the Brexit and other crises (refugees, climate change, trade wars, populist threats) may have led to an increasing awareness for Europe and a perception that European integration may be at risk, which might have activated reflections on Europe and strengthened the formation of a European identity.

It remains to be seen how the most severe post-war recession as a consequence of the Covid-19 pandemic in 2020 will impact on European identity. A lot will depend on whether Europe is perceived to react in a convincing and successful way to the economic and social challenges of these developments.

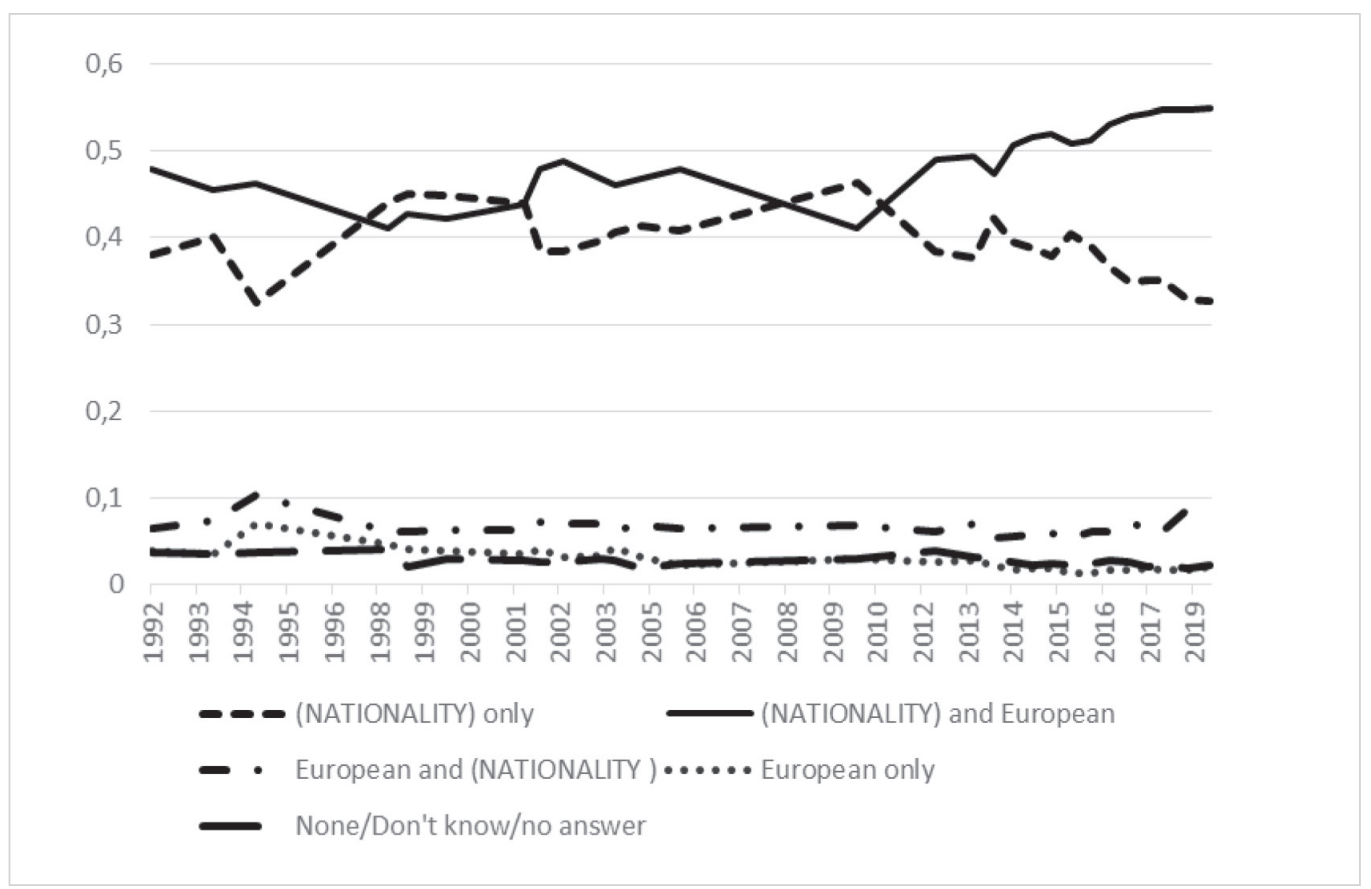

Source: Eurobarometer 1992-2019, Moreno question: "In the near future, do you see yourself as ... ?"; weighted aver-age according to Eurobarometer data for the 'European Union' total.

After this brief aggregate perspective, we dig deeper into the heterogeneity of views among European citizens. Strategies that want to support European identity formation should be based on a clear understanding about the empirically relevant individual drivers. ${ }^{4}$ Only this detailed understanding allows to develop identity-fostering strategies with a promising target group perspective.

4 Beyond the individual dimension the empirical literature has paid substantial attention to national characteristics like, for example, a Member State's economic and social conditions. For a comprehensive recent survey see (Ciaglia, Fuest, \& Heinemann, 2018) 
Figure 2 summarize central insights from a rich literature with a selective focus on relevant individual characteristics. Although the empirical literature on European identity provides some robust messages, an important caveat applies. A good share of the literature offers insights on correlations but does not show causality. For example, an empirical link between studying abroad and European identity can obviously be driven by a reversed causality so that students with a European identity are more likely to go abroad. Moreover, correlations - e.g. between education and socio-economic status - make it difficult to identify the most relevant drivers from a conglomerate of individual factors. With these notes of caution the following picture emerges.

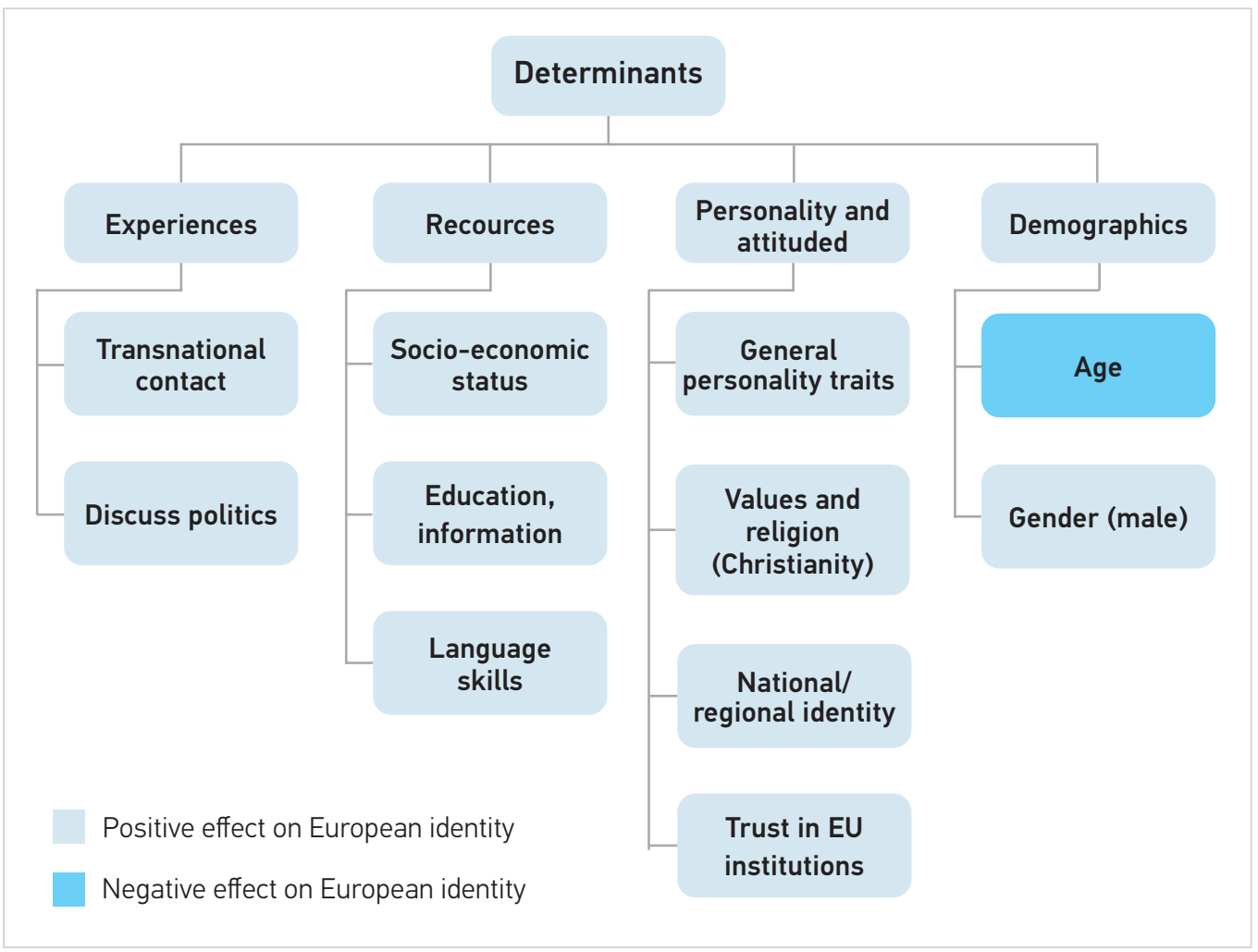

\section{Experiences}

Among individual-level factors, transnational contact has attracted particularly large attention. European identity research has covered various types of exchange that range from travelling (Ceka \& Sojka, 2016; Westle \& Buchheim, 2016) and personal transnational relations (e.g. being an intra-EU immigrant, Verhaegen, Hooghe, \& Quintelier, 2017) to relationships including marriages (Schroedter, Rössel, \& Datler, 2015; Van Mol, De Valk, \& Van Wissen, 2015). While travelling has a positive effect on European identity, being exposed to a high number of tourists at home does not show any effect on European identity (Buscha, Muller, \& Page, 2017). Stoeckel (2016) studies international social interactions of about 1,500 German students and finds that contact increases European identity, particularly for those students who have had a rather weak European identity before.

The EU's Erasmus Impact Study (European Commission, 2014, pp. 130, 151) shows that mobile students and staff do in general feel more attached to Europe than non-mobile individuals, even before going abroad. However, there is no 'additional' effect after having returned from the stay

\section{Empirical insights on determinants}

\section{Figure 2}

Empirically relevant determinants of European identity 
abroad so that the causal effectiveness of Erasmus is not supported. Jacobone and Moro (2015) find a small positive effect of participation in the Erasmus program on European identity - directly, and indirectly through a reduction in national and regional identity and increased cultural exchange confidence, language skills and personal development. Mitchell (2015) concludes that participating in the Erasmus program indeed encourages European identity significantly. Oborune (2015) surveys about 12,000 Erasmus students and finds that about a third of them feels more European after the exchange. Summing up, Kuhn (2015) shows that transnational contacts contribute a lot to European identity formation. However, she also shows that only a small fraction of the population engages in this, namely young, well-educated and relatively wealthy people (similarly Datler, Wallace, \& Spannring, 2005; Mitchell, 2015).

Apart from actual exchange, experience can also grow with a continuous intellectual preoccupation with political and European issues. This conjecture is confirmed as interest in EU issues (Verhaegen \& Hooghe, 2015; Westle \& Buchheim, 2016) as well as discussing about politics (Di Mauro \& Fiket, 2017; Mitchell, 2015; Verhaegen et al., 2017) is also associated with a larger European identity. Also experimental designs that compare a treatment to a control group confirm the link: Participation in a simulation of European politics (Ruenz, 2015) or in deliberation meetings on European issues (Di Mauro \& Fiket, 2017) strengthen European identity. However, the findings of Ruenz (2015) also show that the effect is rather small due to the fact that participants of EU simulations already had high levels of both European identity and EU support before.

\section{Resources}

Closely related to an individual's European experiences is the whole conglomerate of factors summarized as 'resources' that not only includes the socio-economic status but also intellectual and mental capacities. These capacities, in turn, originate from education (including language skills).

The individual socio-economic background seems especially decisive for European identity (Risse, 2015). Waechter (2016) shows that also for minority groups in the EU, the socio-economic situation drives European identity formation. European identity also increases with higher levels of education that is highly correlated with socio-economic status (Ceka \& Sojka, 2016; Curtis, 2016; Mitchell, 2015; Risse, 2015; Verhaegen \& Hooghe, 2015; Verhaegen et al., 2017; Westle \& Buchheim, 2016). Similarly, knowledge (Ceka \& Sojka, 2016; Curtis, 2016; Mitchell, 2015; Verhaegen \& Hooghe, 2015) and information (Bruter, 2003; Di Mauro \& Fiket, 2017; Waechter, 2016) about the EU and politics increases the likelihood to have a European identity.

Non-surprisingly, foreign language proficiency as a particular education dimension is shown to be an important asset to engage in transnational contact for instance, or in knowledge or debating politics, and in turn, European identity (Monter, Grad, Albacete, \& Condor, 2004). Stoicheva (2015) stresses the role of multilingualism for European identity, both as a means to communicate and enter into exchange with people from other EU countries.

\section{Personality and attitudes}

Personality traits and values including religious imprint and trust in European institutions affect European identity as well. Curtis (2016) investigates how personality traits affect European identity in the UK. The study finds that extraversion increases European identity, while agreeableness (in the sense of being gentle and polite) decreases it. Luhmann (2017) finds that pessimists are a lot less likely to feel European.

Postmaterialism (Jung, 2008) and cosmopolitan and liberal values (Risse, 2015) positively affect a supranational or European identity. Curtis (2016) also finds that adhering to Christian religion increases European identity. However, this could also simply be seen as a proxy for cultural closeness. Nelsen 
and Guth (2016) conclude that religion affects European identity: Catholics tend to be more European than Protestants. However, this only holds as long as the community is a majority in a country.

On national identity and regional attachment, Medrano and Gutiérrez (2001) find that both are compatible with European identity. However, Jung (2008) points out that national pride decreases a supranational identity. There seem to be different effects at work here. Ceka and Sojka (2016) for instance uncover that having a strong national identity decreases the cognitive component of European identity, but does not affect the affective component of European identity. Moreover, Westle and Buchheim (2016) discover that those who hold an exclusive European identity are mainly driven by rejecting their national identity. Dehdari and Gehring (2017) show that in Alsace and Lorraine a strong regional identity also relates to a high European identity. This holds especially for the first two generations after World War II. Brigevich (2016) sheds further light on the relationship between regional and European identity in French regions. In fact, she finds that cultural regional identity reduces support for EU institutions, whereas political regional identity increases support. This supports Dehdari's and Gehring's (2017) conclusion that people might seek to 'up-level' (national) political power to the EU so as to increase regional relevance.

A person's trust in EU institutions, democracy and other Europeans (Bruter, 2003; Ceka \& Sojka, 2016; Harrison \& Bruter, 2015; Verhaegen et al., 2017) is positively correlated with European identity although the issue of reversed causality is particularly obvious for this link. Westle and Buchheim (2016) study the changes from exclusive national to dual European and from dual European to exclusive European identity. They show that both changes depend especially on factors related to the civic component of European identity: satisfaction with EU democracy, trust in EU institutions, EU citizens, and EU politics. Moreover, the 'opposite', having trust only in national institutions and citizens, reduces European identity significantly.

\section{Demographics}

Age has been confirmed in the literature as a major determinant of European identity (Risse, 2015). Jung (2008) finds that across the world, young people tend to have higher levels of supranational identity than people at older ages. Secondly, Ceka and Sojka (2016) differentiate between cognitive and affective European identity. They observe that the effect of age has opposing effects in old and new Member States. While in old Member States, cognitive European identity increases with age, the opposite shows for new Member States. As concerns affective European identity, young people from new Member States are even more affective than their peers from old Member States. Waechter (2017) links the generational effect to the numerous opportunities that the EU provides for young people regarding travelling, studying and working abroad.

There are some studies on European identity formation among children, which support many of the above mentioned findings. Agirdag et al. (2012; 2016) investigate European identity formation among Belgian pupils and find that the socio-economic status, both of the child's family as well as the overall school's average, strongly affect European identity: children from working class families are less likely to identify as European. Moreover, boys identify more as European than girls. In contrast, neither age nor religion affect European identity during childhood.

Finally, for the individual-level factors, gender seems to have a small but significant effect on European identity, which remains unexplained in the literature. Male persons are more likely to have a European identity than female persons (Jung, 2008; Verhaegen \& Hooghe, 2015) and also higher levels of EU support (Henjak, Tóka, \& Sanders, 2012).

\section{Robust main findings}

Summing up, this literature provides some largely consensual facts about the relevant drivers of European identity. Overall, key variable groups that are positively associated with identity as a 
Classification of measures and target groups
European are centered on cognitive mobilization (e.g. information, discussing politics), transnational experience (so far largely student exchange), intellectual resources (education, language skills), financial resources and trust in European institutions. Moreover, the literature shows the high correlation of young age, economic status, educational attainments, language skills and transnational contact. Those who are most likely to hold a European identity are young, wealthy, well-educated, and eager to travel, work or study abroad. With other words, the Erasmus target group is precisely one that already has a large disposition to develop a European view. The divide on transnational experience can itself reinforce a European alienation of the more constrained groups. Kuhn (2015) emphasizes potential negative feedback loops of 'social stratification': transnationalism which depends on the social and educational background might even increase the distance between groups and, hence, further endanger a European consensus.

Any strategy to foster European identity should start with a clear understanding about both the specific dimension of identity and the target groups in focus. For that purpose, we first suggest a classification and, second, identify target groups.

Our classification (Table 1) of identity triggers is built on the distinction between the civic and the cultural dimension of European identity. A strategy that wants to activate the perceived commonal-ities of Europeans within their political system (civic dimension) has two groups of triggers. The strategy can either address citizens' involvement in the political decision processes ('input') or aim at improving the provision of the Union's 'outputs' with a high salience. Measures related to the cultural dimension of European identity would have to create space for the experience of shared values for Europeans from the different Member States. This can be achieved either through ap-proaches that simplify transnational contacts and common European experience of different na-tionalities or through European symbols and common stages of a European public. Obviously, single identity triggering programs can also be relevant for both the civic and the cultural dimensions of identity (what explains the double entries in Table 1).

\section{Table 1}

Triggering European identity: Classification and examples

\begin{tabular}{|c|c|c|c|c|}
\hline Dimension & \multicolumn{2}{|c|}{ Civic identity } & \multicolumn{2}{|c|}{ Cultural identity } \\
\hline Moderator & Input & Output & $\begin{array}{l}\text { Transnational } \\
\text { contacts }\end{array}$ & $\begin{array}{l}\text { Symbols and } \\
\text { European }\end{array}$ \\
\hline Example & $\begin{array}{l}\text { (1) European party lists } \\
\text { (2) Citizens' assemblies } \\
\text { (3) Public broadcaster }\end{array}$ & $\begin{array}{l}\text { 4) EU consu-lates } \\
\text { (5) European Waltz } \\
\text { (6) Pension-ers' } \\
\text { Erasmus }\end{array}$ & $\begin{array}{l}\text { (5) European } \\
\text { Waltz } \\
\text { (6) Pension-ers' } \\
\text { Erasmus }\end{array}$ & $\begin{array}{l}\text { (3) Public } \\
\text { broadcaster } \\
\text { (7) Europe Day as } \\
\text { public holiday }\end{array}$ \\
\hline
\end{tabular}

On target groups, the insights from the empirical literature summarized before have straightforward lessons. A focused strategy should try to reach those groups in particular that normally lack the opportunity for European experiences due to resource constraints of the various types. Programs should include those who are less educated, lack language skills and have had less opportunities to accumulate some basic knowledge of the EU and its politics. Particular attention could be paid to groups that lack sufficient resources and opportunities to engage in transnational contact both at home and abroad. The robust negative correlation between age and European identity emphasizes the need to reflect the potential of programs for older citizens that, in their youth, may have lacked the opportunities to spend time abroad. With this target group descrip- 
tion, it becomes obvious that the current sole pre-occupation of European programs with the young and well-educated (Erasmus) needs to be reconsidered.

In the following, we discuss seven exemplary measures and programs for which empirical identity research offers supporting arguments. We have chosen these examples to cover the available broad space of options as far as possible. Some of these measures have been discussed before, others have been developed by the authors (for more details on the measures see Ciaglia et al., 2018). For each of the proposals, we briefly sketch the origin and contents, describe its position in our classification, its target group and both its potential and limitations.

\section{Transnational party lists}

European party lists in the European Parliament have attracted considerable attention in the recent political debate. These have not only been proposed by the French President Macron in his Sorbonne speech about the future of the EU (Macron, 2017) but they have also been discussed within the Parliament for years (e.g., in a report by the Committee on Constitutional Affairs: European Parliament, 2011). More recently again, in February 2018, the European Parliament rejected a proposal to re-allocate the current British seats after Brexit to a transnational constituency (Barbière, 2018), but the issue remains on the political agenda.

The proposal can be classified as an input-related measure fostering the civic dimension of European identity. It does not address a specific stratum of citizens. Target groups are voters of all kind for which identity formation could be fostered through information and discussions ('cognitive mobilization') about the European elections and pan-European policy issues.

Candidates running for seats on transnational party lists would have to win constituencies different to the current local or national definitions. European party families would each set up a list with the lead candidate at the very top. To be successful, candidates from these lists need to get attention across a critical number of EU Member States and, therefore, seek to find policy issues that are of interest for many of them, hence, of a genuine European nature. Clearly, these European messages that have an appeal to voters in various Member States are likely to foster a sense of common European challenges in the election campaigns. Conversely, candidates on European lists will hardly have a chance to qualify through messages centered on narrow country-specific national issues. In this sense, the 'supply' of political messages and policy offers in European collection campaigns can be expected to be more European and to address and raise the perception for common European issues.

Another argument from the political economy of fiscal federalism is that party lists could reduce the interest in local 'pork barrels', i.e. spending items that are highly salient in local constituencies. The resulting 'common pool' disincentive leads to an inefficient neglect of European public goods and the problematic 'juste retour' approach to the EU budget since years because politicians seeking reelection in a local district have to please their local voters (Heinemann, 2006).

From a constitutional justice perspective, a transnational list would contribute to reducing the current misrepresentation of voters from different Member States due to the allocation of seats to Member States. The downside is that the lists could lead even to an overrepresentation of large Member States as their candidates could win a critical mass of voters more easily compared to those from smaller countries (Pukelsheim \& Oelbermann, 2015).

Finally, Hübner et al. (2017) concludes that transnational party lists require a "uniform, EU-wide electoral procedure" (p. 40). This could also be a starting point for striving towards more 'Europeanized' elections
Exemplary

measures consistent with the target group approach 
that might finally even overcome the need for transnational lists. In the long run, insofar genuine transnational political parties come into existence transnational lists could become redundant.

\section{Citizens' assemblies}

The idea to establish European Citizens' Assemblies has first been promoted by NGOs, thinktanks and academics rather than from EU representatives (Organ, 2018). The instrument has been applied on the national level already with Ireland ${ }^{5}$ being a particularly prominent example. With the new Commission, this instrument might get more attention from the top: Ursula von der Leyen, as a candidate for the Commission presidency, had announced a "Conference on the Future of Europe" in which citizens "play a leading and active role" (von der Leyen, 2019).

Similar to transnational party lists, a Citizens' Assembly is a measure related to the civic dimension of identity. It would aim to increase the input legitimacy of EU decision making and offer a stage for a truly European debate of citizens. Different to the party lists innovation with its embedding of a representative system, the Assembly stresses the direct involvement of citizens in the Union's political reflections. Again, it would be a broad measure in terms of its target group which is the part of the population that follows political debates and it is related to the cognitive mobilization for European issues. The idea is that the involvement of 'ordinary citizens' would increase the share of the population that pays attention to a European political debate and, hence, further increases the target group endogenously.

A European Citizens' Assembly would gather a representative sample of the EU population for discussing a relevant und timely political issue. The selection could be organized as a lottery by the Eurobarometer as they have the necessary administrative experience. ${ }^{6}$ For a start, one could think of about 100 to 200 participants in order to ensure practicability. As language might certainly be a barrier, EU institutions could provide for translation services. The final outcome would be a decision (if it's an issue with clear options, e.g. yes/no) or a report (if it's more complex, e.g. guidelines). The file would be sent to all EU and national institutions and be presented to the European Council, the European Parliament, and the Commission College. The report would not have any formal impact, instead it would enrich the political debate and stimulate politics on an issue. The argument is that the Assembly would contribute to forming a 'European demos' on the one hand, and efficiently facilitating insights from the people to the policy-making process.

A downside is that even the lottery element is no safe precaution that the selection will really be representative as the acceptance of an invitation will be strongly driven by individual features like education and political interests.

Despite its practical limitations, the measure is promising from this paper's point of view as the kind of debate in such an Assembly would be able to develop shared European policy perspectives and help to perceive various other European commonalities.

\section{European public broadcaster}

The idea of a genuine EU-wide public broadcaster was mentioned in the Adoninno Report that suggested "the development of a truly European television channel" (Commission of the European Communities, 1985, p. 22), but, since then, it did not receive serious consideration. Currently, with Euronews, there exists only one EU-wide broadcaster. However, it does not air on usual TV and is, therefore, not easily accessible for a large audience. Even though, several national public service broadcasters take part in Euronews (via the European Broadcasting Union), the majority

5 Ireland's Citizens Assembly website: https://www.citizensassembly.ie/en/Home/.

6 In Ireland, selection was organized by an opinion poll agency, too, and was based on a few criteria to ensure a representative sample: gender, age, region, and social class. 
of shares is held privately (Euronews, 2020). Instead, a public broadcaster is usually required to focus on news from all regions, civic education, preserving cultural heritage and addressing various interests of the audience to reach a most broad coverage of the people. ${ }^{7}$

A European public broadcaster could appeal to both the cultural and civic dimension of European identity. It is supposed to encourage knowledge, information, and discussions about EU politics and lead to the valuable 'cognitive mobilization' on European debates. Hence, it could impact positively on the 'input' dimension of the European political process. If it reaches a critical level auf audience, it could contribute to the development of a European public. Its target group are those that have an interest in political developments from another than their national perspective. Clearly, its potential will be higher for the part of the population with above-average education that has an interest in policy debates.

A European public broadcaster could be founded by all national public service broadcasters and the governing body could be composed of their representatives only. Accordingly, it would be financed and supported technically by all national public service broadcasters together. The aim is to provide an easily accessible, independent, and genuinely European source of information. The broadcaster could start with one main task which would be to air all public meetings, hearings, and press conferences of EU institutions, in particular from the European Council, the European Parliament and the European Commission, and the new Citizens' Assembly (or Citizens' Dialogues). Additionally, there could be news shows during the day, produced with contributions from all national and regional broadcasters. The aim is to allow a broadcaster that meaningfully complements national public service broadcasters and does not position in competition to them.

Public broadcasters are not uncontroversial. The main counter-argument is that people are forced to pay for a broadcaster independent from their actual media consumption. Supporters emphasize the financial and political independence of national public service broadcasters and their mission to provide information most accurately and objectively and with less pressure to focus on what 'sells best'. The added value of a European public service broadcaster could be its contribution for preserving media pluralism even in Member States where this was recently challenged.

\section{EU consulates}

The idea to establish an 'EU embassy with 27 flags' has been proposed in the literature with a strong focus on potential cost savings due to potential economies of scale (Bertelsmann Stiftung, 2013, p. 56). According to this proposal, EU embassies would provide consular services for all EU citizens. Beyond the cost argument, such an innovation would clearly have potential to make citizens perceive the Union as a provider of valuable services. Hence, it relates to the output dimension of the civic understanding of European identity. EU embassies and consulates would address the part of population that travels internationally, be it for touristic or professional reasons. These groups could perceive EU infrastructure as providing insurance and assistance, e.g. through the issuance of 'laissez-passez' travel documents in case they lost their passport or in cases of illness, crime victims or other emergencies.

Already the Adonnino Report (Commission of the European Communities, 1985, p. 21) has identified assistance of European citizens in third countries as European task where Member States should also assist nationals from other Community countries. Today, EU countries already co-operate with regard to Schengen provisions or visa application centers in third countries (for details see Bertelsmann Stiftung, 2013). Moreover, the European External Action Service has a network across the world with regard to foreign policy issues and diplomatic assistance for the 
High Representative of the EU. However, it does not provide direct consular support for citizens. The Lisbon Treaty has made a first step in that direction by prescribing that every EU Member State's embassy shall provide for consular support for all EU citizens (Art. 20 TFEU). Nevertheless, a genuine EU consulate that replaces national representations would be a salient step beyond national cooperation towards European service provision.

EU consular offices are considered to bring significant financial and administrative savings. Moreover, it could provide a better coverage of third countries whereas the current situation is characterized by an inefficient spatial clustering of EU Member States' consulates in few places (Bertelsmann Stiftung, 2013). The key counter-argument is that Member States have special national interests that might not adequately be addressed by EU representations. An obvious possible compromise could be that services of a homogenous type (travel documents, visa) are pooled whereas diplomatic contacts continue to be provided by national teams.

\section{European Waltz}

The 'European Waltz' is a recent new idea proposed by the authors (Ciaglia et al., 2018). Together with the measure described in the next section (Pensioners' Erasmus, see below) it belongs, like the classical Erasmus programs, to mobility-fostering approaches. It appeals to both the civic (the EU as enabler for professional cross-border exchange) and the cultural dimension of European identity (contact with colleagues in other EU countries fostering a sense of communality). Policy makers regularly see Erasmus (for students in tertiary education and vocational training) as the model case for a successful program to foster European identity through cross-border experiences. While participation is certainly beneficial as a personal experience, there is limited evidence that Erasmus actually has a positive causal impact on European identity (beyond correlation, see section 3 for the Erasmus impact assessment literature). The reasons are self-selection biases, through which most of young and mobile citizens participate that tend to have already a positive European attitude and often belong to the more affluent part of society. It might therefore be beneficial to broaden the target group.

The 'European Waltz' would specifically address the working population. It would support employed adults to work and live some time in another EU country. It could start with a couple of weeks and be insightful for both the visitor and the hosting company. The idea (and the name) builds on the journeymen in craftsmanship who travel around to learn from other habits and skills and, thereby, to improve and broaden their knowledge. Priority should be given to employment sectors and qualifications that have a domestic character and regularly lack the opportunity of foreign work experience like the health sectors, the civil service, craftsmanship, retail and others (for further institutional details see Ciaglia et al., 2018). Taking part in such an exchange would not only improve working skills, but also foster exchange ('transnational contact'), and getting to know other ways of life ('cognitive mobilization'). Moreover, people would feel a direct benefit from the EU's attempts to facilitate working abroad (output dimension of civic identity).

The backing from the empirical identity literature summarized above for the 'Waltz' is obvious: The program addresses the transnational experience and resource channel that has proven to be important for identify formation. It is also based on a careful target group analysis. In contrast to the students' Erasmus program, the Waltz would not be as costly. The main challenge is to establish the network and facilitate the placements. However, the first and easiest step could be to align regulation to ensure an "EU leave" and related social security safeguards. Similar to the student's Erasmus program, this one could also be prone to self-selection. In contrast, however, this program would not only affect the ones on the 'Waltz' but also their hosting company, their 
home company and their guest family. Given the practical issues remaining to be resolved, pilot programs could be a sensible first step.

\section{Pensioners' Erasmus}

The 'Pensioners' Erasmus' is our second own proposal that, like the preceding one, is built on the idea to enable transnational experiences for specific target groups that often lack the resources to do so on their own (for details see Ciaglia et al., 2018). Similar to the 'Waltz', it has potential to stimulate both the civic (EU as output provider) and the cultural dimension (encounters with fellow-pensioners) of European identity.

The program would have a financial, an administrative and an infrastructure related part. Firstly, similar to Erasmus, the program would provide financial support for short-term journeys up to a couple of weeks. Eligible journeys would have to fulfill certain conditions that exclude the use of resources for normal tourist trips and prescribe true encounters with the host country population. These conditions could be linked to certified cultural, historical, language or social seminars or projects. In addition, pensioners who would like to engage with European pensioners at home, could be supported with information on funding a 'buddy program' to invite and accompany pensioners from abroad.

The obvious challenge for the program are high budgetary costs, the mentioned self-selection of 'good Europeans' into the program, and windfall gains for affluent pensioners who love travelling. Therefore, a means-test could be recommendable in order to concentrate the budget on the pensioners with resource constraints. The program could also be limited to people immediately after pension entry when they are still relatively open and in a phase of re-orientation. The big advantage is that the program could reach a target group that so far has been rather neglected and that deserves special attention given the results of the empirical identity literature summarized above (section 4).

\section{Public holiday on Europe day 9 May}

The Adonnino Report (Commission of the European Communities, 1985, p. 24) has considered to dedicate the Europe Day $9^{\text {th }}$ May commemorating the Schuman Declaration to special information and teaching campaigns and special celebrations of the European institutions. These limited intentions still characterize today's practice of the Europe Day, which suffers from a low visibility (Larat, 2019). One recent initiative from Members of European Parliament and civic groups was to make the day a public holiday for all Member States and EU institutions (Lee, 2019).

A European public holiday would classify as European symbols like the European flag or anthem that foster a sense of European community. Generally, days of commemoration have the function to strengthen such feelings even if there is no universal consensus on the past event. In the course of time, commemorating activities are increasingly detached from the actual historical event but create a collective image just because of the ritual repetition (Onken, 2007). Besides this 'cultural' dimension there is also a 'civic dimension' insofar the EU would be perceived to promote one common day off work to celebrate.

The strength of the European bank holiday would be its far-reaching salience through all groups of society with a particular visibility for the active workforce. However, there are potential risks attached, both with regard to transition and the long-run. The introduction would raise the issue of compensating cuts in other holidays in order to avoid economic losses. Hence, there might be social groups that would have to sacrifice on of 'their' holidays (e.g. the churches). An additional particular problem is that $9^{\text {th }}$ May, as the day of victory over Nazi Germany, has competing meanings that could polarize at least in those countries where 'Victory Day' played a role in the (Soviet) past, i.e. for the Russian minorities in the Baltic states (Onken, 2007). 
With our analysis of target groups and political legitimacy, we developed and discussed seven pro-posals to strengthen European identity. Our analysis does not recommend one particular measure as the single crucial and most promising approach to foster European identity. All measures that we have discussed are well grounded in our target group analysis and have their particular strengths and weaknesses. The overview demonstrates the broad spectrum of potential measures which are promising and worth further consideration. Compared to this spectrum of action, the EU's current approaches are rather centered on programs like Erasmus which might be too narrow in terms of the target group, which is typically considered young, well-educated and comparatively wealthy. This might neglect exactly those groups with the highest obstacles to European experiences and perceptions. Accordingly, there seems to be a gap between a highly differentiated and compre-hensive academic identity research and the narrow and ad hoc European policy debate. This con-clusion raises questions to which extent academic European integration research always reach their potential policy audiences.

A final clarifying note is important. A sense of European identity is helpful for any type of European cooperation both within and outside the institutions of the European Union. Hence, programs fos-tering European identity are to be distinguished from approaches that seek to mobilize support for the EU and its status quo or specific integration steps. With our contribution, we explicitly do not take sides with one particular model of European integration. Moreover, we do not think it should be the objective of European politics let alone academic research to manipulate ('nudge') citizens to become 'better Europeans'. This would be paternalistic. Identity belongs to a person's most pri-vate sphere and is up to own evaluations and decisions. With some justification, Shore (2006) criti-cizes an instrumental use of European identity as a non-justified elite project. However, the kind of measures discussed in this contribution might advance European identity mainly by overcoming biases in information and prejudices. This type of approach which is based on exchange and improved information should not be seen as an undue manipulation of preferences. On the contrary, it advances rational decision making as an essential ingredient for a stable and fruitful democratic system and peaceful international cooperation on the European continent.

\section{References}

Agirdag, O., Huyst, P., \& Van Houtte, M. (2012). Determinants of the formation of a European identity among children: Individual-and school-level influences. Journal of Common Market Studies, 50(2), 198-213. https://doi.org/10.1111/j.1468$5965.2011 .02205 . x$

Agirdag, O., Phalet, K., \& Van Houtte, M. (2016). European identity as a unifying category: National vs. European identification among native and immigrant pupils. European union politics, 17(2), 285302. https://doi.org/10.1177/1465116515612216

Akerlof, G. A., \& Kranton, R. E. (2000). Economics and Identity. Quarterly Journal of Economics, 115(3), 715-753. https://doi. org/10.1162/003355300554881

Barbière, C. (2018). European Parliament votes against transnational lists. EURACTIV, 07 February 2018.

Bertelsmann Stiftung. (2013). The European Added Value of EU Spending: Can the EU Help its Member States to Save Money? Gütersloh: Bertelsmann Stiftung.
Brigevich, A. (2016). Regional identity and support for Europe: distinguishing between cultural and political social identity in France. Regional \& Federal Studies, 26(4), 475-507. https://doi.org/10.1080/13 597566.2016 .1223057

Bruter, M. (2003). Winning hearts and minds for Europe: The impact of news and symbols on civic and cultural European identity. Comparative political studies, 36(10), 1148-1179. https://doi. org/10.1177/0010414003257609

Bruter, M. (2004). On what citizens mean by feeling 'European': perceptions of news, symbols and borderless-ness. Journal of ethnic and migration studies, 30(1), 21-39. https://doi. org/10.1080/1369183032000170150

Buscha, F., Muller, D., \& Page, L. (2017). Can a common currency foster a shared social identity across different nations? The case of the euro. European Economic Review, 100, 318-336. https://doi. org/10.1016/j.euroecorev.2017.08.011 
Carey, S. (2002). Undivided loyalties: is national identity an obstacle to European integration? European union politics, 3(4), 387-413. https://doi. org/10.1177/1465116502003004001

Ceka, B., \& Sojka, A. (2016). Loving it but not feeling it yet? The state of European identity after the eastern enlargement. European union politics, 17(3), 482503. https://doi.org/10.1177/1465116516631142

Ciaglia, S., Fuest, C., \& Heinemann, F. (2018). What a feeling?! How to promote 'European Identity'. EconPol Policy Report 09/2018, October.

Commission of the European Communities. (1973). The Copenhagen Summit Conference: Declaration on European Identity. Bulletin of the European Communities, 12, 118-122.

Commission of the European Communities. (1985). A People's Europe, Reports from the ad hoc Committee Bulletin of the European Communities, Supplement(7).

Cram, L. (2012). Does the EU need a navel? Implicit and explicit identification with the European Union. Journal of Common Market Studies, 50(1), 71-86. https://doi.org/10.1111/j.1468-5965.2011.02207.x

Curtis, K. A. (2016). Personality's effect on European identification. European union politics, 17(3), 429456. https://doi.org/10.1177/1465116516635754

Datler, G., Wallace, C., \& Spannring, R. (2005). What leads young people to identify with Europe?: An exploration of" exposure" to Europe and resources for identification among young Europeans, Sociological Series 69. Institute for Advanced Studies, Vienna.

Dehdari, S. H., \& Gehring, K. (2017). The origins of common identity: Division, homogenization policies and identity formation in Alsace-Lorraine. CESifo Working Paper No. 6556.

Di Mauro, D., \& Fiket, I. (2017). Debating Europe, transforming identities: assessing the impact of deliberative poll treatment on identity. Italian Political Science Review/Rivista Italiana di Scienza Politica, 47(3), 267-289. https://doi.org/10.1017/ipo.2016.26

Euronews. (2020). Euronews, About Euronews, www.euronews.com/about.

European Commission. (2014). The Erasmus Impact Study: Effects of mobility on the skills and employability of students and the internationalisation of higher education institutions. In: Publications Office of the European Union Luxembourg.

European Commission. (2017). Communication from the Commission to the European Parliament, the Council, the European Economic and Social Committee and the Committee of the Regions, Strengthen- ing European Identity through Education and Culture, 14.11.2017, COM(2017) 673 final. Strasbourg

European Parliament. (2011). Report on a proposal for a modification of the Act concerning the election of the Members of the European Parliament by direct universal suffrage of 20 September 1976. Committee on Constitutional Affairs (2009/2134(INI)).

Friese, H., \& Wagner, P. (2002). Survey article: the nascent political philosophy of the European polity. The Journal of Political Philosophy, 10(3), 342-364. https://doi.org/10.1111/1467-9760.00156

Harrison, S., \& Bruter, M. (2015). Media and identity: The paradox of legitimacy and the making of European citizens. In T. Risse (Ed.), European Public Spheres - Politics is Back (pp. 165-189): Cambridge University Press. https://doi.org/10.1017/ CB09781139963343.010

Heinemann, F. (2006). Das common pool-Problem in der EU-Finanzverfassung. Zeitschrift für Staatsund Europawissenschaften/Journal for Comparative Government and European Policy, 4(2), 188213. https://doi.org/10.1515/ZSE.2006.010

Henjak, A., Tóka, G., \& Sanders, D. (2012). Citizens and the European polity: mass attitudes towards the European and national polities. In D. Sanders, P. Magalhães, \& G. Tóka (Eds.), (pp. 169-209): Oxford University Press. https://doi.org/10.1093/acprof:oso/9780199602339.003.0008

Hobolt, S. B. (2012). Citizen satisfaction with democracy in the European Union. Journal of Common Market Studies, 50, 88-105. https://doi. org/10.1111/j.1468-5965.2011.02229.x

Hübner, D., Blockmans, S., \& Russack, S. (2017). Regroup and Reform. Ideas for a more responsive and effective European Union, Report of a CEPS Task Force. In. Brussels: CEPS.

Jacobone, V., \& Moro, G. (2015). Evaluating the impact of the Erasmus programme: skills and European identity. Assessment \& Evaluation in Higher Education, 40(2), 309-328. https://doi.org/10.1080 /02602938.2014.909005

Jung, J. K. (2008). Growing supranational identities in a globalising world? A multilevel analysis of the World Values Surveys. European journal of political research, 47(5), 578-609. https://doi.org/10.1111/ j.1475-6765.2008.00779.x

Kaina, V. (2013). How to reduce disorder in European identity research. European Political Science, 12(2), 184-196. https://doi.org/10.1057/eps.2012.39

Kaina, V., \& Karolewski, I. P. (2013). EU governance and European identity. Living Reviews in European 
Governance, 8(1), 1-57. https://doi.org/10.12942/ lreg-2013-1

Kaina, V., Karolewski, I. P., \& Kuhn, S. (2015). European identity revisited: New approaches and recent empirical evidence: Routledge. https://doi. org/10.4324/9781315714905

Kuhn, T. (2015). Experiencing European integration: Transnational lives and European identity: Oxford University Press. https://doi.org/10.1093/acprof:oso/9780199688913.001.0001

La Barbera, F., \& Ferrara, P. C. (2012). Being European in a social dilemma: The effect of European identity on cooperation. Testing, Psychometrics, Methodology in Applied Psychology, 19(3), 165-175.

Larat, F. (2019). Present-ing the Past: Political Narratives on European History and the Justification of EU Integration. German Law Journal, 6(2), 273290. doi:10.1017/S2071832200013638 https://doi. org/10.1017/S2071832200013638

Lee, A. (2019). Europe Day initiative calls for 9 May to become public holiday. Retrieved from https:// www.euractiv.com/section/future-eu/news/europe-day-initiative-calls-for-9-may-to-becomepublic-holiday/

Luhmann, S. (2017). A Multi-Level Approach to European Identity: Does Integration Foster Identity? Journal of Common Market Studies, 55(6), 13601379. https://doi.org/10.1111/jcms. 12554

Macron, E. (2017). Initiative pour l'Europe - Pour une Europe souveraine, unie, démocratique, Université Sorbonne, 26.09.2017, www.elysee.fr/ declarations/article/initiative-pour-l-europe-discours-d-emmanuel-macron-pour-une-europesouveraine-unie-democratique/.

Medrano, J. D., \& Gutiérrez, P. (2001). Nested identities: national and European identity in Spain. Ethnic and racial studies, 24(5), 753-778. https://doi. org/10.1080/01419870120063963

Mitchell, K. (2014). Does European Identification Increase Support for Further Economic Integration? Journal of European Integration, 36(6), 601-618. do i:10.1080/07036337.2014.916286 https://doi.org/1 $0.1080 / 07036337.2014 .916286$

Mitchell, K. (2015). Rethinking the 'Erasmus Effect' on European Identity. Journal of Common Market Studies, 53(2), 330-348. https://doi.org/10.1111/ jcms. 12152

Monter, M. R., Grad, H., Albacete, G. G., \& Condor, S. (2004). The role of language skills and foreign country experiences in the development of European identity. Change, 36(3), 273-292.
Moreno Fernández, L. (1986). Decentralisation in Britain and Spain: the cases of Scotland and Catalonia, PhD thesis, University of Edinburgh.

Nelsen, B. F., \& Guth, J. L. (2016). Religion and the creation of European identity: The message of the flags. The Review of Faith \& International Affairs, 14(1), 80 88. https://doi.org/10.1080/15570274.2016.1145476 Oborune, K. (2015). Becoming more EUropean or European after ERASMUS? Politeja-Pismo Wydziału Studiów Międzynarodowych i Politycznych Uniwersytetu Jagiellońskiego, 12(37), 75-94. https://doi.org/10.12797/Politeja.12.2015.37.06

Onken, E.-C. (2007). The Baltic states and Moscow's 9 May commemoration: Analysing memory politics in Europe. Europe-Asia Studies, 59(1), 2346. doi:10.1080/09668130601072589 https://doi. org/10.1080/09668130601072589

Organ, J. (2018). How an EU citizens' assembly could help to renew European democracy. The Conversation, Blog, November 23, 2018, https:// theconversation.com/how-an-eu-citizens-assembly-could-help-to-renew-european-democracy-98894.

Pukelsheim, F., \& Oelbermann, K.-F. (2015). Reinforcing uniformity in the European election act: gentle interim arrangements in 2019 Towards systematic double-proportionality in 2024. In A. Duff, F. Pukelsheim, \& K.-F. Oelbermann (Eds.), The Electoral Reform of the European Parliament: composition, procedure and legitimacy (pp. 18-25). Brussels: European Parliament.

Risse, T. (2015). A community of Europeans?: Transnational identities and public spheres: Cornell University Press.

Ruenz, P. (2015). Beyond teaching: Measuring the effect of EU simulations on European identity and support of the EU. European Political Science, 14, 266-278. https://doi.org/10.1057/eps.2015.23

Scharpf, F. W. (1999). Governing in Europe: Effective and democratic?:OxfordUniversity Press. https://doi. org/10.1093/acprof:oso/9780198295457.001.0001

Schroedter, J. H., Rössel, J., \& Datler, G. (2015). European identity in Switzerland: the role of intermarriage, and transnational social relations and experiences. The Annals of the American Academy of Political and Social Science, 662(1), 148-168. https://doi.org/10.1177/0002716215595394

Shore, C. (2006). 'In uno plures'(?) EU Cultural Policy and the Governance of Europe. Cultural Analysis, 5(2006), 7-26.

Stoeckel, F. (2016). Contact and community: The role of social interactions for a political identity. 
Political Psychology, 37(3), 431-442. https://doi. org/10.1111/pops.12295

Stoicheva, M. (2015). What policy of multilingualism can foster European identity formation? Politeja-Pismo Wydziału Studiów Międzynarodowych i Politycznych Uniwersytetu Jagiellońskiego, 12(37), 107-121. https://doi.org/10.12797/Politeja.12.2015.37.08

Van Klingeren, M., Boomgaarden, H. G., \& De Vreese, C. H. (2013). Going Soft or Staying Soft: Have Identity Factors Become More Important Than Economic Rationale when Explaining Euroscepticism? Journal of European Integration, 35(6), 689-704. do i:10.1080/07036337.2012.719506 https://doi.org/1 0.1080/07036337.2012.719506

Van Mol, C., De Valk, H. A., \& Van Wissen, L. (2015). Falling in love with (in) Europe: European bi-national love relationships, European identification and transnational solidarity. European union politics, 16(4), 469489. https://doi.org/10.1177/1465116515588621

Verhaegen, S., \& Hooghe, M. (2015). Does more knowledge about the European Union lead to a stronger European identity? A comparative analysis among adolescents in 21 European member states. Innovation: The European Journal of Social Science Research, 28(2), 127-146. https://doi.org/1 $0.1080 / 13511610.2014 .1000836$

Verhaegen, S., Hooghe, M., \& Quintelier, E. (2017). The effect of political trust and trust in European citizens on European identity. European Political Science Review, 9(2), 161-181. https://doi. org/10.1017/S1755773915000314 von der Leyen, U. (2019). Opening Statement in the European Parliament Plenary Session by Ursula von der Leyen, Candidate for President of the European Commission, 16 July 2019, Strasbourg.

Waechter, N. (2016). Introduction to the construction and the interplay of European, national and ethnic identities in Central and Eastern Europe. In: Taylor \& Francis.

Waechter, N. (2017). Instrumental and cultural considerations in constructing European identity among ethnic minority groups in Lithuania in a generational perspective. Nationalities Papers, 45(4), 651-668. https://doi.org/10.1080/00905992 .2016 .1258048

Westle, B., \& Buchheim, R. G. (2016). National and European Identification - Their Relationship and its Determinants. In B. Westle \& P. Segatti (Eds.), European identity in the context of national identity: Questions of identity in sixteen European countries in the wake of the financial crisis (pp. 93-128). Oxford: Oxford University Press. https://doi.org/10.1093/ acprof:0so/9780198732907.003.0004

Westle, B., \& Segatti, P. (2016). European identity in the context of national identity: Questions of identity in sixteen European countries in the wake of the financial crisis. Oxford: Oxford University Press. White, J. (2012). A common European identity is an illusion. In H. Zimmermann \& A. Dür (Eds.), Key controversies in European integration (pp. 103111): Palgrave Macmillan.

\section{CIAGLIA SARAH}

\section{$\mathrm{PhD}$ candidate}

European Institute, London School of Economics and Political Science

\section{Fields of interests}

Economic and fiscal policy, political economy, European integration.

\section{Address}

Houghton Street, London WC2A 2AE, United Kingdom

\section{FUEST CLEMENS}

Prof. Dr. Dr. h.c.

Ifo Institute

\section{Fields of interests}

Economic and fiscal policy, international taxation, European integration.

\section{Address}

Poschingerstraße 5, 81679

München, Germany

Phone: +4989 92241430

\section{HEINEMANN FRIEDRICH}

Prof. Dr.

ZEW - Leibniz-Centre for

European Economic Research

\section{Fields of interests}

Fiscal policy and taxation, political economy, European integration.

\section{Address}

L7, 1, 68161 Mannheim, Germany Phone: +49621 1235149
About the authors 